\title{
Preparation of Poly(Hydroxamic Acid) for Separation of Zr/Y, Sr System
}

\author{
Khaled F. Hassan, ${ }^{1}$ Shaban A. Kandil, ${ }^{1}$ Hossam M. Abdel-Aziz, ${ }^{2}$ and Tharwat Siyam² \\ ${ }^{1}$ Cyclotron Facility, Nuclear Research Centre, Atomic Energy Authority, Cairo 13759, Egypt \\ ${ }^{2}$ Hot Lab Center, Atomic Energy Authority, Cairo, Postal Code 13759, Egypt \\ Correspondence should be addressed to Shaban A. Kandil, shabankandil@hotmail.com
}

Received 5 November 2010; Revised 6 January 2011; Accepted 14 January 2011

Academic Editor: Antonio Martín-Esteban

Copyright (C) 2011 Khaled F. Hassan et al. This is an open access article distributed under the Creative Commons Attribution License, which permits unrestricted use, distribution, and reproduction in any medium, provided the original work is properly cited.

\begin{abstract}
Poly(hydroxamic acid) resin (PHA) was prepared by modification of polyacrylamide (PAAm) prepared through $\gamma$-irradiation technique and used for the first time in separation of $\mathrm{Zr}$ (IV) from $\mathrm{Y}$ (III) and $\mathrm{Sr}$ (II) as a simulation mode for the purification of ${ }^{89} \mathrm{Zr}$ from its parents ( $\mathrm{Y}$ or $\mathrm{Sr}$ ). The adsorption behaviors of zirconium, yttrium, and strontium on the prepared PHA resin in different media, namely, hydrochloric acid, acetate buffer, and citrate buffer were studied as a function of $\mathrm{pH}$. In addition, in cation-exchange column chromatography experiments using PHA, three different eluants, namely, $10^{-5} \mathrm{~mol} / \mathrm{L} \mathrm{HCl}$, acetate buffer $\mathrm{pH} 3.5$, and $2 \mathrm{~mol} / \mathrm{L} \mathrm{HCl}$, were employed for elution of $\mathrm{Zr}(\mathrm{IV}), \mathrm{Y}(\mathrm{III})$ and $\mathrm{Sr}(\mathrm{II})$, respectively, where $\mathrm{Zr}(\mathrm{IV}), \mathrm{Y}(\mathrm{III})$ and Sr(II) were eluted in amounts of $80 \%, 99.9 \%$, and $100 \%$, respectively. The purification process of $\mathrm{Y}$ (III) from $\mathrm{Zr}(\mathrm{IV})$ was carried out using regenerated PHA.
\end{abstract}

\section{Introduction}

Hydroxamic acids have been known for their chelation ability with heavy metals. They have been found to be effective chelating ligands with the ions such as $\mathrm{V}^{5+}, \mathrm{Fe}^{3+}$, $\mathrm{Mo}^{6+}, \mathrm{Ti}^{4+}, \mathrm{Hg}^{2+}, \mathrm{Cu}^{2+}$, and $\mathrm{UO}_{2}^{2+}[1]$. Number of chelating polymers, containing hydroxamic acid group, have been prepared from various starting materials using different methods. Poly(hydroxamic acid) was synthesized from polyacrylamide at different conditions [2-5]. They have been known for various analytical applications. For example, extraction and purification of uranium [6], extraction and separation of gold and silver [7], separations of iron from copper, nickel, and cobalt [8], copper from lead [9], uranium from neodymium [10], and cobalt from copper and nickel [11]. Also a preliminary study on application of sago starch-based poly(hydroxamic acid) resin for extraction of lanthanide group elements $\left(\mathrm{La}^{3+}, \mathrm{Dy}^{3+}, \mathrm{Pr}^{3+}, \mathrm{Ce}^{3+}, \mathrm{Nd}^{3+}\right.$, $\mathrm{Gd}^{3+}, \mathrm{Eu}^{3+}$, and $\mathrm{Tb}^{3+}$ ) from aqueous media was done by using batch technique [12]. The chelating polymer materials are mainly used in analytical, industrial and radiochemical laboratories [12].
One of the main tasks of radiochemical laboratories is the purification of radionuclides from their matrix. The medical interest radionuclides such as $\beta^{+}$emitters have been developed [13]. One of them, ${ }^{89} \mathrm{Zr}\left(T_{1 / 2}=78 \mathrm{~h}\right)$, can be produced by either of two routes, namely, alpha irradiation of strontium [14] or proton irradiation of yttrium [15]. For radiochemical purification of zirconium from yttrium and strontium, early studies were based on the solvent extraction and the ion-exchange chromatography [16-18], but only a limited extent of purification is still there. Here, in this study, the Poly(hydroxamic acid) resin (PHA) will be prepared by modification of polyacrylamide (PAAm) (that was prepared through $\gamma$-irradiation technique) and will be used for the first time in separation of $\mathrm{Zr}$ from $\mathrm{Y}$ and $\mathrm{Sr}$ as a simulation mode for promising rise in purification of ${ }^{89} \mathrm{Zr}$ from its parents ( $\mathrm{Y}$ and $\mathrm{Sr}$ ).

\section{Experimental}

2.1. Chemicals and Reagents. Acrylamide used in this study was obtained from Merck (Darmstadt, Germany). $\mathrm{N}, \mathrm{N}$-methylene-bis-acrylamide (NMBA) was used as a 
crosslinking agent, and it was obtained from Sigma-Aldrich (St. Loius, MO, USA). Hydrochloric acid and sodium hydroxide were used to adjust the $\mathrm{pH}$ of the medium were obtained from Merck, hydroxylamine hydrochloride from Fluka (Buchs, Switzerland). $\mathrm{Y}_{2} \mathrm{O}_{3}$ 99.97\% from Koch-Light Laboratories Ltd, (Cambridge, England); zirconyl chloride octahydrate $\mathrm{ZrOCl}_{2} \cdot 8 \mathrm{H}_{2} \mathrm{O}$ 98\% (Aldrich); strontium carbonate $99.99 \%$ from Alfa Aesar Co., Karlsruhe, Germany). Other chemicals used were of analytical reagent grade.

2.2. Instrumentation. The content of the separated material was determined via inductively coupled plasma optical emission spectrometry (ICP-OES) using the system ULTIMA2 ICP, Jobin Yvon S. A., France. The specifications of the device and operating conditions are given in Tables 1 and 2, respectively.

2.2.1. Gamma Cell. A cobalt-60 gamma cell of type MC-20 (Russia) was used as irradiation source, with a dose rate of 2 $\mathrm{KGy} \mathrm{h}^{-1}$; it has two chambers of 5 liters.

2.2.2. FT-IR Analysis. Infrared spectra of polymer samples with $\mathrm{KBr}$ pellets were obtained from FT-IR spectrometer (Bomen, Hartman \& Borunz spectrometer, Model MB 157, Canada).

2.3. Preparation of Poly(Hydoxamic Acid). Crosslinked Polyacrylamide (PAAm) was prepared by radiation-induced polymerization of acrylamide monomers in aqueous solution in the presence of (NMBA) as a crosslinking agent [19]. About $10 \mathrm{~g}$ of acrylamide and $1 \mathrm{~g}$ of (NMBA) were dissolved in $100 \mathrm{~mL}$ distilled water. The mixture was transferred into glass ampoules and nitrogen gas was purged into the ampoules to remove air from the solution. The glass ampoules were sealed and then subjected to ${ }^{60} \mathrm{Co} \gamma$-rays at a dose rate of $2 \mathrm{kGyh}^{-1}$. After irradiation, the crosslinked obtained polymers were cut into small pieces that were washed in acetone for removal of unreacted monomers then dried and stored. The percent conversion was determined gravimetrically and was about $90 \%$.

For preparation of PHA in hydrogen form [20], the solution of a calculated amount of hydroxylamine hydrochloride and solution of sodium hydroxide were added to a suspension of dry crosslinked PAAm. The resulting mixture was stirred for $5 \mathrm{~min}$ at the room temperature. The reaction was continued for $6 \mathrm{~h}$ at $70^{\circ} \mathrm{C}$. Ammonia was liberated during the reaction. After completion of the reaction, the resin was separated from the solution by filtration and washed several times with water. Then, the resin was treated with $3 \mathrm{~mol} / \mathrm{L}$ $\mathrm{HCl}$ solution for at least $5 \mathrm{~min}$. Finally, the resin was filtered and washed several times with water till it is chlorine-free, and then dried at $50^{\circ} \mathrm{C}$ to a constant weight.

2.4. Batch Experiments. For separation of $\operatorname{Zr}(\mathrm{IV})$ from both $\mathrm{Y}(\mathrm{III})$ and $\mathrm{Sr}(\mathrm{II})$, it is necessary to determine the distribution coefficient. A stock solution of $5000 \mathrm{mg} / \mathrm{L}$ of each zirconium, yttrium, and strontium (strontium was only dissolved in a cold $\mathrm{HCl}$ ) was prepared by dissolving in a hot concentration $\mathrm{HCl}$ solution. The solution was evaporated to incipient
TABle 1: Specifications of the ULTIMA 2 ICP spectrometer.

\begin{tabular}{lc}
\hline Parameter & Specification \\
\hline Optical mounting & Czerny-Turner \\
Far UV option & Yes \\
Focal length & $1 \mathrm{~m}$ \\
Gratings: number of grooves per $\mathrm{mm}$ & $2400 \mathrm{~g} / \mathrm{mm}$ \\
Resolution & $5 \mathrm{pm} 120-320 \mathrm{~nm}$ \\
Thermoregulation & $10 \mathrm{pm} 320-800 \mathrm{~nm}$ \\
Type of generator & $32 \pm 0.1^{\circ} \mathrm{C}$ \\
Torch & $40.68 \mathrm{MHz}$, Solid state \\
\hline
\end{tabular}

TABLE 2: Operating conditions.

\begin{tabular}{lc}
\hline Parameter & Condition \\
\hline Rf-power & $1000 \mathrm{~W}$ \\
Plasma gas flow rate & $12 \mathrm{~L} / \mathrm{min}$ \\
Auxiliary gas flow rate & $0 \mathrm{~L} / \mathrm{min}$ \\
Sheath gas flow rate & $0.2 \mathrm{~L} / \mathrm{min}$ \\
Nebulizer flow & $0.8 \mathrm{~L} / \mathrm{min}$ at 3 bars \\
Type of nebulizer & Glass concentric \\
Type of spray chamber & Glass cyclonic \\
Argon humidifier & Yes \\
Injector tube diameter & $3 \mathrm{~mm}$ \\
Sample uptake & $1 \mathrm{~mL} / \mathrm{min}$ \\
Emission lines for & \\
Zr & 339.198 \\
Sr & 216.596 \\
Y & 319.561 \\
\hline
\end{tabular}

dryness, and the residue dissolved in $100 \mathrm{~mL}$ of double distilled water. To $100 \mu \mathrm{L}$ of this solution, $4.9 \mathrm{~mL}$ different concentrations of $\mathrm{HCl}$ or other mediums such as $0.1 \mathrm{~mol} / \mathrm{L}$ of citrate buffer or $0.1 \mathrm{M}$ of acetate buffer at variable $\mathrm{pH}$ were added to a fixed weight of resin $(50 \mathrm{mg})$. The contents were shaken for 2 hours to attain equilibrium. From the separated two phases (solid and liquid), the distribution coefficient $\left(K_{d}\right)$ was obtained using the following equation [21]:

$$
K_{d}=\frac{C_{\mathrm{ads}}}{C_{\mathrm{unads}}} \times \frac{V}{m},
$$

where $C_{\mathrm{ads}}$ is the concentration sorbed on the resin, $C_{\mathrm{unads}}$ is the remaining concentration in solution, $V$ is the volume of the aqueous phase in $\mathrm{mL}$, and $\mathrm{m}$ is the mass of the resin in grams. For all batch experiments, determination of zirconium, yttrium, and strontium concentrations will be measured by using inductively coupled plasma optical emission spectrometry (ICP-OES).

2.5. Cation-Exchange Column Chromatography. An extensive study for separation of $\mathrm{Zr}(\mathrm{IV})$ from both $\mathrm{Y}(\mathrm{III})$ and $\mathrm{Sr}$ (II) via PHA resin using different eluants, namely, $10^{-5} \mathrm{~mol} / \mathrm{L} \mathrm{HCl}$, acetate buffer, and $2 \mathrm{~mol} / \mathrm{L} \mathrm{HCl}$ was carried out in this work.

A $100 \mathrm{~mL}$ stock solution containing $100 \mathrm{ppm}$ of each $\mathrm{Zr}$, $\mathrm{Y}$, and $\mathrm{Sr}$ dissolved in $10^{-5} \mathrm{~mol} / \mathrm{L} \mathrm{HCl}$ was loaded onto a 


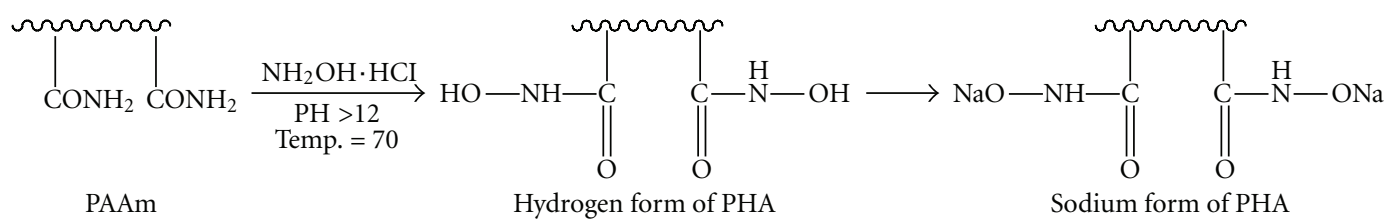

Scheme 1: Conversion of PAAm to PHA.

glass column, $22 \mathrm{~cm}$ long $\times 1.5 \mathrm{~cm}$ in diameter, packed with PHA with depth of $2 \mathrm{~cm}$. Quartz wool was put at the top exchanger to prevent disturbance of the adsorbent particles during addition of solution and to regulate flow of solutions through the column. A $1 \mathrm{~mL}$ stock sample was retained as a control. Load samples were taken to test for breakthrough during this step. Inductively coupled plasma (ICP) analysis of the load samples showed no breakthrough of $\mathrm{Y}$ and $\mathrm{Sr}$ from the column while $\mathrm{Zr}$ passes through. The column was washed with further $50 \mathrm{~mL}$ of the same loading solution (without metals). About $150 \mathrm{~mL}$ of $0.1 \mathrm{~mol} / \mathrm{L}$ acetate buffer with $\mathrm{pH}$ 3.5 and flow rate $(\sim 1.5 \mathrm{~mL} / \mathrm{min})$ was used for the elution process of Sr. The samples were collected $(\sim 16.5 \mathrm{~mL})$; a total of 9 samples were collected and analyzed by ICP. To remove the $\mathrm{Y}$, about $150 \mathrm{~mL}$ of $2 \mathrm{~mol} / \mathrm{L} \mathrm{HCl}$ was used. The details of the separation process will be given below.

\section{Results and Discussion}

3.1. Preparation of the Resin. PHA resin was prepared from the reaction of the corresponding crosslinked PAAm with hydroxylamine hydrochloride [20], and sodium hydroxide. A schematic presentation of possible reaction between PAAm and hydroxylamine hydrochloride with sodium hydroxide to form hydrogen and sodium form of PHA is shown in Scheme 1.

3.2. FT-IR Analysis. The IR spectra recorded for the (a) polyacrylamide (PAAm), (b) poly(hydroxamic acid) (PHA), and (c) metal loaded PHA samples are given in Figure 1. From Table 3, the infrared spectrum of crosslinked PAAm shows the characteristic absorption bands of amide (N$\mathrm{H}), \mathrm{CH}_{2}$ stretching and carbonyl groups at 3401, 2998, and $1649 \mathrm{~cm}^{-1}$, respectively. The infrared spectrum of PHA resin showed the characteristic absorption bands of hydroxamic $(\mathrm{O}-\mathrm{H})$, amide $(\mathrm{N}-\mathrm{H})$, carbonyl and $(\mathrm{N}-\mathrm{O})$ groups at 3200 , 3444,1670 and $930 \mathrm{~cm}^{-1}$. The absorption band at $2862 \mathrm{~cm}^{-1}$ is related to $\mathrm{C}=\mathrm{N}$ group in enol form of hydroxamic acid. Comparison of spectra of the PHA sample and metal ion loaded PHA sample show a shift in the N-O band from 930 to $775 \mathrm{~cm}^{-1}$ in the metal ion loaded sample as a result of interaction of corresponding groups with metal ions. This indicates a strong interaction of metal ions with the $\mathrm{N}-\mathrm{O}$ group of the sorbent and as the $\mathrm{M}-\mathrm{O}$ bond is stronger, the $\mathrm{N}-\mathrm{O}$ bond exhibits lower stretching frequency. Additional peaks at around $700 \mathrm{~cm}^{-1}$ can also be seen which are characteristic of $\mathrm{O}-\mathrm{M}-\mathrm{O}$ stretching vibrations. The possible interactions between metal ions and PHA polymers are shown in Scheme 2 [22].

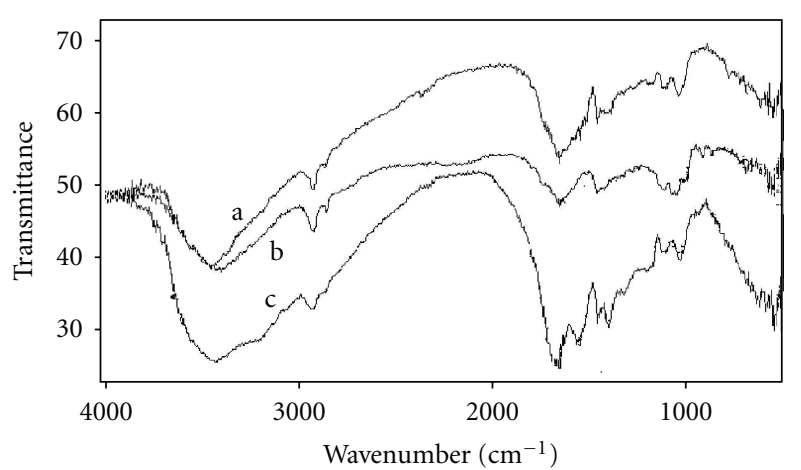

Figure 1: FTIR spectra of (a) PAAm, (b) PHA and (c) metal loaded PHA.

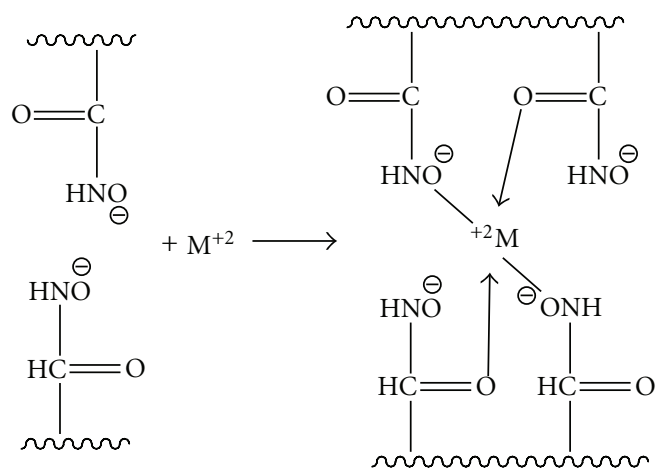

Scheme 2: Possible interactions between metal ions and PHA resin.

3.3. Adsorption Behaviors of Zr, Y, and Sr on Cation Exchangers. The adsorption behaviors of zirconium, yttrium, and strontium on synthetic PHA resin in different media, namely, hydrochloric acid, acetate buffer, and citrate buffer were studied. However, the effect of equilibrium time has been studied as a function of uptake for each element in batch mode, where the equilibrium was achieved after $2 \mathrm{~h}$ of shaking.

3.3.1. Hydrochloric Acid. Figure 2 shows the relationship between the distribution coefficients ( $K_{d}$-values) of these elements and the concentration of hydrochloric acid on PHA, where $\mathrm{Y}$ and $\mathrm{Sr}$ both showed the same adsorption behaviour over the acidity range of $10^{-5}-1 \mathrm{~mol} / \mathrm{L}$ where within the acidity range of $10^{-5}-10^{-3} \mathrm{~mol} / \mathrm{L}$ their $K_{d}$-values increase with increasing the concentration of the acid and then decrease with acidity increase till $0.1 \mathrm{~mol} / \mathrm{L}$. On the other hand, for zirconium, the $K_{d}$-values increase globally 
TABLE 3: FTIR spectra of PAAm, PHA, and metal loaded PHA.

\begin{tabular}{|c|c|c|c|c|}
\hline \multirow{2}{*}{ Original groups } & \multirow{2}{*}{ Absorption bands of original groups $\left(\mathrm{cm}^{-1}\right)$} & \multicolumn{3}{|c|}{ Experimental absorption bands $\left(\mathrm{cm}^{-1}\right)$} \\
\hline & & PAAm & PHA & PHA-M \\
\hline \multicolumn{5}{|l|}{ Amide: } \\
\hline Free $>$ NH stretching (amide II) & 3500,3400 & 3401 & 3444 & 3449 \\
\hline$>\mathrm{C}=\mathrm{O}$ stretching $($ amide $\mathrm{I})$ & 1650 & 1649 & 1670 & 1649 \\
\hline \multicolumn{5}{|l|}{ Aliphatic: } \\
\hline$-\mathrm{CH}_{2}$ stretching & $2926-2853$ & 2998,2851 & & 2919 \\
\hline$-\mathrm{CH}_{2}$ bending & $1485-1445$ & 1400 & & 1418 \\
\hline$-\mathrm{CH}_{3}$ bending & $1470-1430$ & & & \\
\hline \multicolumn{5}{|l|}{ Hydroxyl: } \\
\hline Free $\mathrm{OH}$ stretching & $3650-3590$ & & & \\
\hline Bonded $\mathrm{OH}$ & $3400-3200$ & & 3200 & 3449 \\
\hline \multicolumn{5}{|l|}{ Amine: } \\
\hline $\mathrm{C}-\mathrm{N}$ stretching & 1410 & 1400 & 1400 & 1416 \\
\hline NH stretching & $3000-2700$ & & & \\
\hline Chelate compounds & $3200-2440$ & & & 2919 \\
\hline Metal-O bond & $<1000$ & & & 775 \\
\hline
\end{tabular}

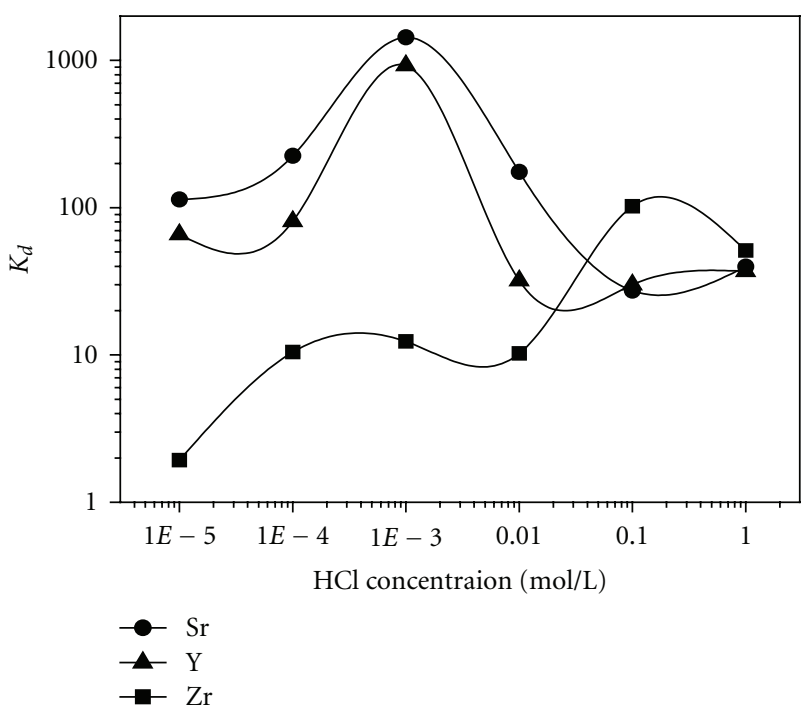

Figure 2: Distribution coefficients of $\mathrm{Zr}(\mathrm{IV}), \mathrm{Y}(\mathrm{III})$ and $\mathrm{Sr}(\mathrm{II})$ as a function of $\mathrm{HCl}$ concentration on PHA resin, shaking time 2 hours.

with $\mathrm{HCl}$ concentration from $10^{-5} \mathrm{~mol} / \mathrm{L}$ to $1 \mathrm{~mol} / \mathrm{L}$ where at $10^{-5} \mathrm{~mol} / \mathrm{L} \mathrm{HCl}$ zirconium showed no specific adsorption $\left(K_{d} \sim 2\right)$ while over the concentration range $10^{-4}-10^{-2} \mathrm{~mol} / \mathrm{L}$ the adsorbability was relatively low and almost constant $(\sim 10)$; however, the adsorbability after $10^{-2} \mathrm{~mol} / \mathrm{L}$ was rather high. The results given also show that the adsorbability in the reverse order, $\mathrm{Sr}(\mathrm{II})>\mathrm{Y}(\mathrm{III})>\mathrm{Zr}(\mathrm{IV})$, this may be due to the formation of hydrated complexes of $\mathrm{Y}$ in diluted acid and zirconium is hydrolysed in aqueous $\mathrm{HCl}$ of varying concentrations; a variety of intermediate hydrolysis products, such as the oxochlorides $\mathrm{MOCl}_{2}$, are formed [23].

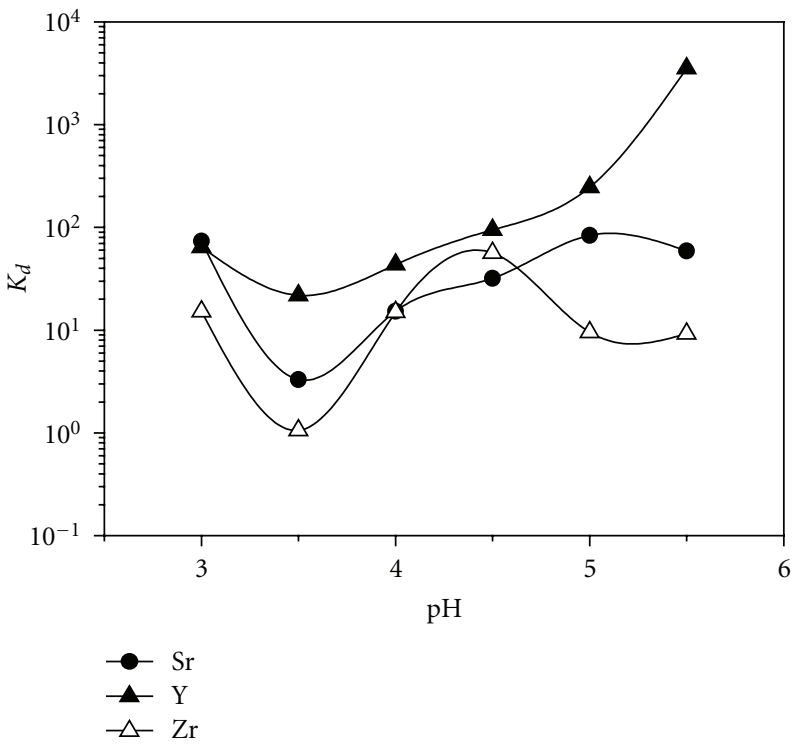

Figure 3: Distribution coefficients of $\mathrm{Zr}(\mathrm{IV}), \mathrm{Y}(\mathrm{III})$, and $\mathrm{Sr}(\mathrm{II})$ as a function of $\mathrm{pH}$ of $0.1 \mathrm{~mol} / \mathrm{L}$ acetate buffers on PHA resin, shaking time 2 hours.

3.3.2. $0.1 \mathrm{~mol} / \mathrm{L}$ Acetate Buffer. Figure 3 illustrates the adsorption behavior of $\mathrm{Zr}, \mathrm{Y}$, and $\mathrm{Sr}$ in $0.1 \mathrm{~mol} / \mathrm{L}$ acetate buffer over the $\mathrm{pH}$ range 3 to 5.5 . Where at $\mathrm{pH} 3.5$ they have the drop in $K_{d}$-values. After this drop over the $\mathrm{pH}$ range $3.5-5.5$, the adsorbability of Y and Sr increase gradually with raising the $\mathrm{pH}$ value. It is also observed that the adsorbability of $\mathrm{Y}$ is higher than that of Sr. While for $\mathrm{Zr}$, after this drop, the adsorbability increases till $\mathrm{pH} 4.5$ and then decreases with raising the $\mathrm{pH}$ to 5.5 . 
3.3.3. 0.1 mol/L Citrate Buffer. The adsorption behaviours of these elements in $0.1 \mathrm{~mol} / \mathrm{L}$ citrate buffer over the $\mathrm{pH}$ range 3 to 5.5 on the PHA exchanger were studied (Figure 4). As shown from the given results, their adsorbabilities were low and almost constant over the range of $\mathrm{pH} 3-5.5$ (for $\mathrm{Y} \sim 25$ and, for $\mathrm{Zr}$ and $\mathrm{Sr} \sim 10$ ) except at $\mathrm{pH} 5.5$, zirconium gives no significant absorption $\left(K_{d} \sim 2\right)$. However, the adsorption behaviours on cation-exchanger (Dowex 50WX8) as discussed by Kandil et al. [16] for these elements differ drastically from values for PHA where zirconium showed significant adsorbability that is constant with varying the $\mathrm{pH}$ from 3.5 to 5.5 , while for strontium the $K_{d}$-value decreased gradually with changing the $\mathrm{pH}$ from 3.5 to 5.5. The adsorbability of the trivalent element $(\mathrm{Y})$ decreased sharply by increasing the $\mathrm{pH}$ from 3.5 to 4.5 , and by continuing the increasing of $\mathrm{pH}$ to 5.5 the adsorbability of yttrium disappeared $\left(K_{d} \sim 2\right)$.

3.4. PHA-Column Chromatography for the Separation of $\mathrm{Zr}$ from $Y$ and $S r$. From batch mode, the optimum conditions for separation of $\mathrm{Zr}$ from both $\mathrm{Y}$ and $\mathrm{Sr}$ were obtained which have been used in the column mode where the column chromatography is applicable for dealing with radioactive material. Practically, from all given results on PHA in batch mode, these elements presented a significant contrast that could facilitate separation of $\mathrm{Zr}$ from both $\mathrm{Y}$ and $\mathrm{Sr}$. Additionally, in the column mode, the effective parameter is the flow rate related to the time. However, in the loading step, $100 \mathrm{ml}$ has been loaded with flow rate $1.5 \mathrm{~mL} / \mathrm{min}$. During the loading, all yttrium and strontium were adsorbed on the resin while zirconium passed through the column. This means that separation of $\mathrm{Zr}$ from both $\mathrm{Y}$ and $\mathrm{Sr}$ has occurred (the main task of the work). In more details the elution profile for separation of $\mathrm{Zr}$ from both $\mathrm{Y}$ and $\mathrm{Sr}$ was given in Figure 5. As described above, for PHA exchanger a $100 \mathrm{~mL}$ stock solution containing $100 \mathrm{ppm}$ of each $\mathrm{Zr}, \mathrm{Y}$, and $\mathrm{Sr}$ dissolved in $10^{-5} \mathrm{~mol} / \mathrm{L} \mathrm{HCl}$ was loaded onto a glass column, $22 \mathrm{~cm}$ long $\times 1.5 \mathrm{~cm}$ in diameter, packed with PHA with depth of $2 \mathrm{~cm}$. At this molarity of $\mathrm{HCl}$ zirconium showed no specific adsorption $\left(K_{d} \sim 2\right.$, Figure 2$)$. So zirconium passed through the column with percentage $80 \%$ of initial amount. Further washing by this molarity of $\mathrm{HCl}$ showed no zirconium pass through the column while yttrium and strontium still remained on the column (their $K_{d}$-values are rather high, Figure 2). For removal of strontium, $0.1 \mathrm{~mol} / \mathrm{L}$ acetate buffer $\mathrm{pH} 3.5$ is suitable for this purpose (Figure 3). Before elution of $\mathrm{Sr}$, it is necessary to adjust the $\mathrm{pH}$ of the column by continuous flowing of $0.1 \mathrm{~mol} / \mathrm{L}$ acetate buffer $\mathrm{pH}$ 3.5. All amount of strontium passed through the column while the residual of zirconium and all yttrium were still adsorbed on the column. Complete elution of $\mathrm{Y}$ was done using $2 \mathrm{~mol} / \mathrm{L} \mathrm{HCl}$ where all yttrium were collected in $100 \mathrm{~mL}$. The elution of $\mathrm{Y}$ was accompanied by elution of residual zirconium. Therefore, further purification is needed.

3.5. Purification Step. The $100 \mathrm{~mL}$ of $2 \mathrm{~mol} / \mathrm{L} \mathrm{HCl}$ containing the whole yttrium and the residual zirconium was evaporated to incipient dryness, and the residue dissolved in $100 \mathrm{~mL}$ of

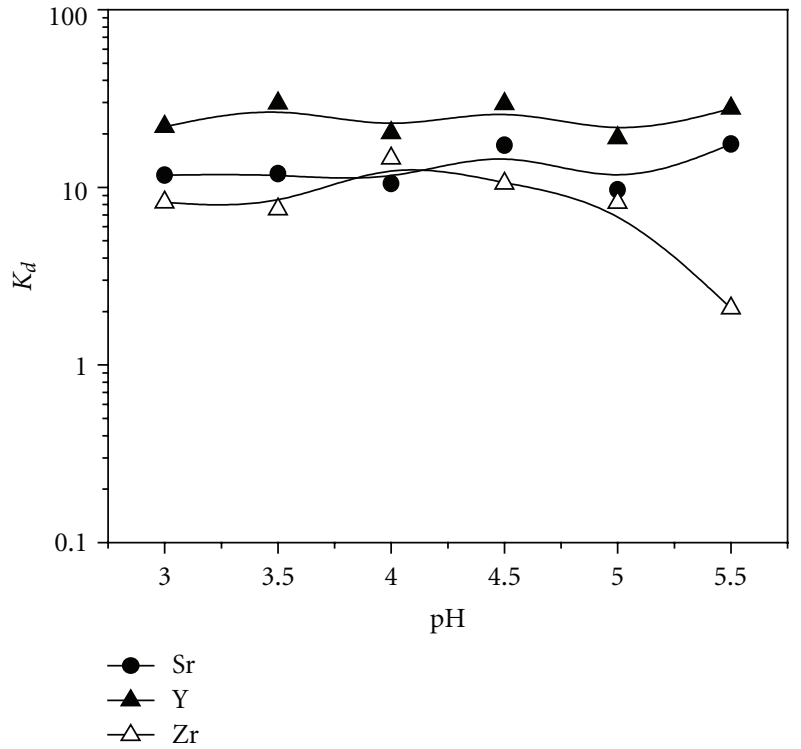

FIGURE 4: Distribution coefficients of $\mathrm{Zr}$ (IV), Y(III), and $\mathrm{Sr}(\mathrm{II})$ as a function of $\mathrm{pH}$ of $0.1 \mathrm{~mol} / \mathrm{L}$ citrate buffers on PHA resin, shaking time 2 hours.

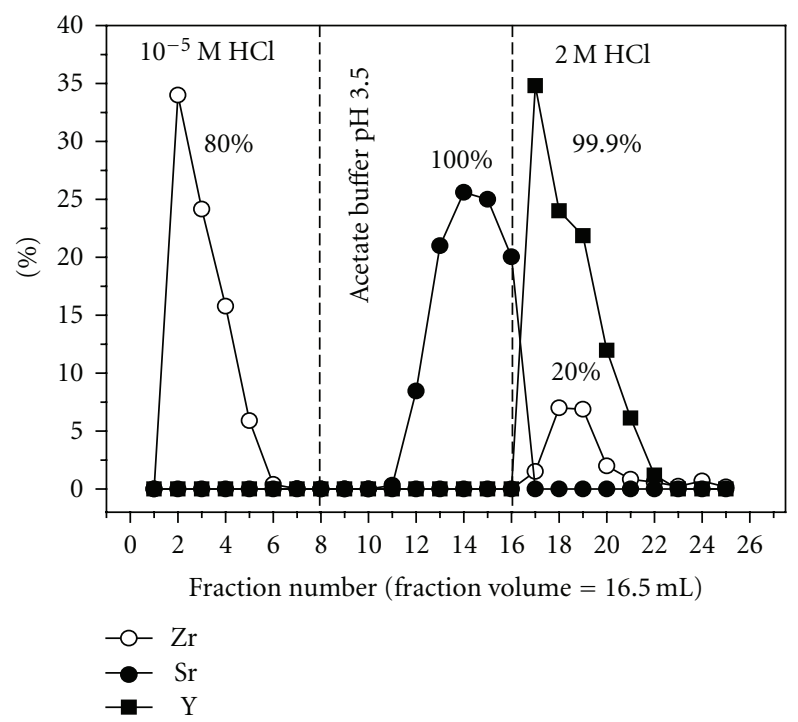

Figure 5: Elution profile of $\mathrm{Zr}(\mathrm{IV}), \mathrm{Y}$ (III) and $\mathrm{Sr}$ (II) from a column packed with PHA resin. Fraction volume $=16.5 \mathrm{~mL}$.

double distilled water. The solution was loaded onto a glass column of the same dimensions packed with a new portion of $\mathrm{PHA}$ at flow rate $1.5 \mathrm{~mL} / \mathrm{min}$. The residual $\mathrm{Zr}$ passed through the column while yttrium remained on the column. Again all yttrium was eluted by $2 \mathrm{~mol} / \mathrm{L} \mathrm{HCl}$.

Regarding the recent work [16], separation of radiozirconium (IV) from both Y(III) and Sr(II) has been carried out using the Dowex 50W-X8 (cation exchanger) column chromatography and Dowex $21 \mathrm{~K}$ (anion exchanger) column chromatography. The separation efficiency for $\mathrm{Zr}$ from both elements together by Dowex $50 \mathrm{~W}-\mathrm{X} 8$ and Dowex $21 \mathrm{~K}$ was $75 \%$ and $22 \%$, respectively. It appears from our results 
TABle 4: Comparison between PHA and ion-exchanger resins [16] on separation efficiency of $\mathrm{Zr}$ from both $\mathrm{Y}$ and $\mathrm{Sr}$.

\begin{tabular}{lccc}
\hline Ion exchanger & Dowex 50W-X8 & Dowex 21K & PHA \\
\hline Separation efficiency \% & 75 & 22 & $\sim 100$ \\
\hline
\end{tabular}

that the zirconium was completely separated $(\sim 100 \%)$ from $\mathrm{Sr}$ (II) in one step and from $\mathrm{Y}$ in two steps using PHA column chromatography (Table 4). However, the process in this work was done by employing the inactive elements. The investigated method could be applied for the separation of radiozirconium from both parents ( $\mathrm{Y}$ and $\mathrm{Sr}$ ).

\section{Conclusion}

Poly(hydroxamic acid) resin (PHA) was prepared by modification of polyacrylamide (PAAm) and characterized by IR. From the presented study, the PHA-column chromatography was employed in separation of $\mathrm{Zr}$ (IV) from $\mathrm{Y}$ (III) and $\mathrm{Sr}$ (II), where the presented two-step route for purification of $\mathrm{Zr}$ from Y(III) was done while purification of $\mathrm{Zr}$ from $\mathrm{Sr}$ (III) was achieved in one step. The investigated method using PHA could be applied in purification of ${ }^{89} \mathrm{Zr}$ from its parents (Y or Sr).

\section{References}

[1] A. Jemal, R. Siegel, E. Ward, Y. Hao, J. Xu, and M. J. Thun, "Cancer statistics," CA: A Cancer Journal for Clinicians, vol. 59, pp. 225-249, 2009.

[2] A. J. Domb, E. G. Cravalho, and R. Langer, "Synthesis of poly(hydroxamic acid) from poly(acrylamide)," Journal of Polymer Science, Part A, vol. 26, no. 10, pp. 2623-2630, 1988.

[3] Y. Isikver, D. Saraydin, and N. Sahiner, "Poly(hydroxamic acid) hydrogels from poly(acrylamide): preparation and characterization," Polymer Bulletin, vol. 47, no. 1, pp. 71-79, 2001.

[4] D. Saraydin and Y. Çaldiran, "In vitro dynamic swelling behaviors of polyhydroxamic acid hydrogels in the simulated physiological body fluids," Polymer Bulletin, vol. 46, no. 1, pp. 91-98, 2001.

[5] T. S. Lee, D. W. Jeon, J. K. Kim, and S. I. Hong, "Formation of metal complex in a poly(hydroxamic acid) resin bead," Fibers and Polymers, vol. 2, no. 1, pp. 13-17, 2001.

[6] F. Vernon, "Chelating ion exchangers-the synthesis and uses of poly(hydroxamic acid) resins," Pure and Applied Chemistry, vol. 54, no. 11, pp. 2151-2158, 1982.

[7] F. Vernon and W. M. Zin, "Chelating ion-exchangers containing $\mathrm{n}$-substituted hydroxylamine functional groups-part 6: sorption and separation of gold and silver by a polyhydroxamic acid," Analytica Chimica Acta, vol. 123, pp. 309-313, 1981.

[8] F. Vernon and H. Eccles, "Chelating ion-exchangers containing n-substituted hydroxylamine functional groups-part IV: column separations on a hydroxamic acid resin," Analytica Chimica Acta, vol. 83, pp. 187-193, 1976.

[9] A. Shah and S. Devi, "Separation of lead and copper on a series of chelating ion-exchange resins-part I," The Analyst, vol. 110, no. 12, pp. 1501-1504, 1985.

[10] D. M. Mohammed, "Separation of uranium from neodymium in a mixture of their oxides," The Analyst, vol. 112, pp. 11791181, 1987.
[11] A. Shah and S. Devi, "Poly(hydroxamic acid) chelating resins part II: separation of zinc from cadmium and of cobalt from copper and nickel," The Analyst, vol. 112, no. 3, pp. 325-328, 1987.

[12] M. Z. Ab Rahman, M. L. Rahman, M. J. Haron et al., "Preliminary study on application of sago starch based poly(hydroxamic acid) resin for extraction of lanthanide group elements from aqueous media," Malaysian Journal of Analytical Sciences, vol. 7, no. 2, pp. 453-456, 2001.

[13] S. M. Qaim, "Cyclotron production of medical radionuclides," in Handbook of Nuclear Chemistry, A. Vértes, S. Nagy, and Z. Klencsár, Eds., vol. 4, p. 47, Kluwer Acadmic, Dordrecht, The Netherlands, 2003.

[14] S. A. Kandil, I. Spahn, B. Scholten et al., "Excitation functions of $(\alpha, \mathrm{xn})$ reactions on $\mathrm{Rb}$ and $\mathrm{Sr}$ from threshold up to $26 \mathrm{MeV}$ : possibility of production of Y, Y and Zr," Applied Radiation and Isotopes, vol. 65, no. 5, pp. 561-568, 2007.

[15] H. M. Omara, K. F. Hassan, S. A. Kandil, F. E. Hegazy, and Z. A. Saleh, "Proton induced reactions on Y with particular reference to the production of the medically interesting radionuclide Zr," Radiochimica Acta, vol. 97, no. 9, pp. 467471, 2009.

[16] S. A. Kandil, B. Scholten, Z. A. Saleh, A. M. Youssef, S. M. Qaim, and H. H. Coenen, "A comparative study on the separation of radiozirconium via ion-exchange and solvent extraction techniques, with particular reference to the production of $\mathrm{Zr}$ and $\mathrm{Zr}$ in proton induced reactions on yttrium," Journal of Radioanalytical and Nuclear Chemistry, vol. 274, no. 1, pp. 45-52, 2007.

[17] C. G. Leichman, K. Chansky, J. S. Macdonald et al., "Biochemical modulation of 5-fluorouacil through dihydropyrimidine dehydrogenase inhibition: a Southwest Oncology Group phase II trial of eniluracil and 5-fluorouracil in advanced resistant colorectal cancer," Investigational New Drugs, vol. 20, no. 4, pp. 419-424, 2002.

[18] F. D. S. Butement and S. M. Qaim, "New radioisotopes of niobium and molybdenum- $\mathrm{I}^{88} \mathrm{Nb}$," Journal of Inorganic and Nuclear Chemistry, vol. 26, no. 9, pp. 1481-1489, 1964.

[19] T. Siyam, "Development of acrylamide polymers for the treatment of waste water," Designed Monomers and Polymers, vol. 4, no. 2, pp. 107-168, 2001.

[20] D. Saraydin, Y. Isikver, and N. Sahiner, "Uranyl ion binding properties of poly(hydroxamic acid) hydrogels," Polymer Bulletin, vol. 47, no. 1, pp. 81-89, 2001.

[21] E. R. Tompkins and S. W. Mayer, "Ion exchange as a separations method. III. Equilibrium studies of the reactions of rare earth complexes with synthetic ion exchange resins," Journal of the American Chemical Society, vol. 69, no. 11, pp. 2859-2865, 1947.

[22] S. Pal, V. Ramachandhran, S. Prabhakar, P. K. Tewari, and M. Sudersanan, "Polyhydroxamic acid sorbents for uranium recovery," Journal of Macromolecular Science, vol. 43, no. 4-5, pp. 735-747, 2006.

[23] N. N. Greenwood and A. Earnshaw, Chemistry of the Elements, Elsevier, Amsterdam, The Netherlands, 2nd edition, 1997. 


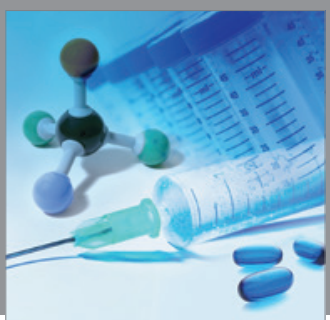

International Journal of

Medicinal Chemistry

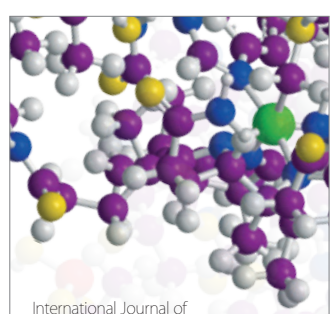

Carbohydrate Chemistry

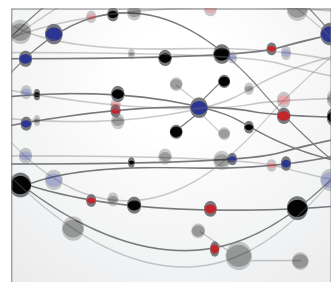

The Scientific World Journal
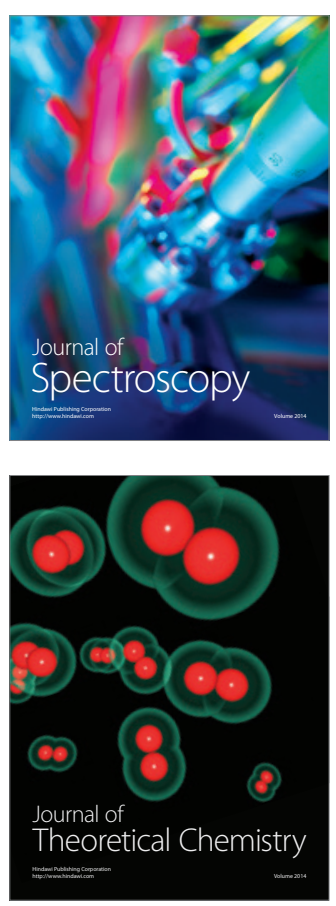
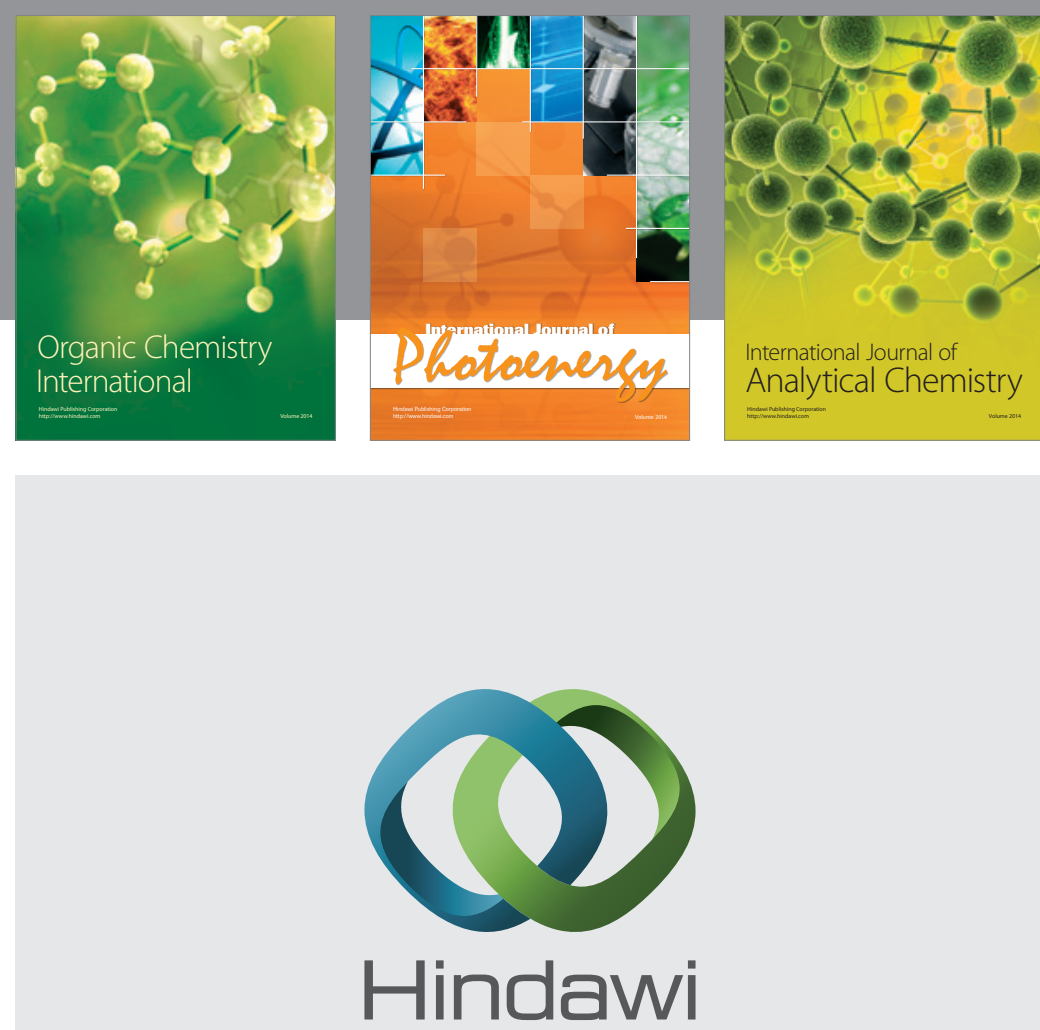

Submit your manuscripts at

http://www.hindawi.com
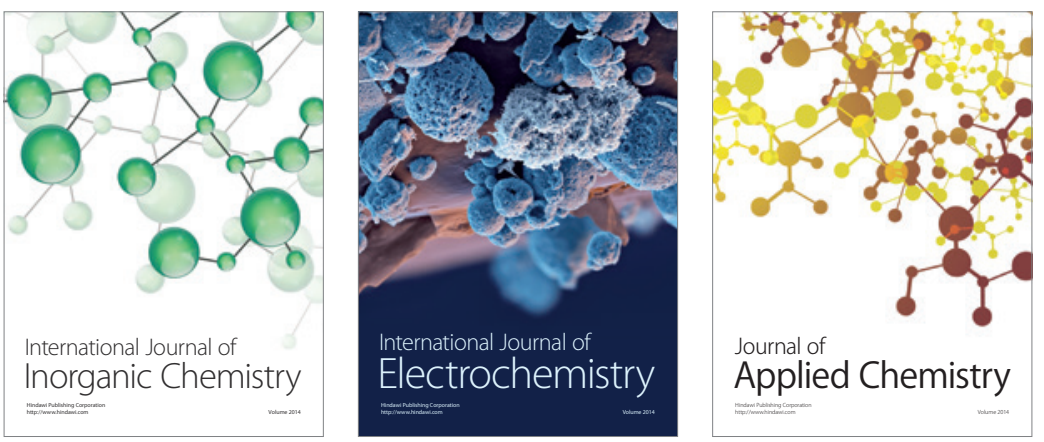

Journal of

Applied Chemistry
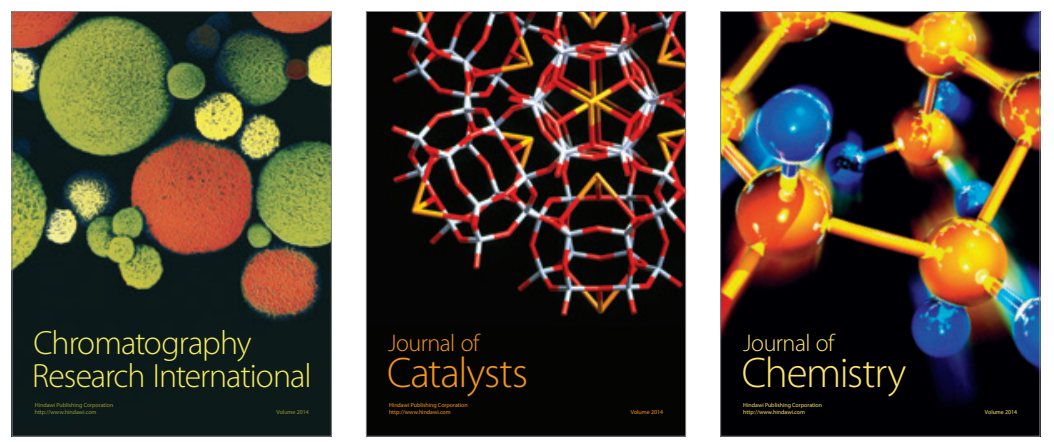
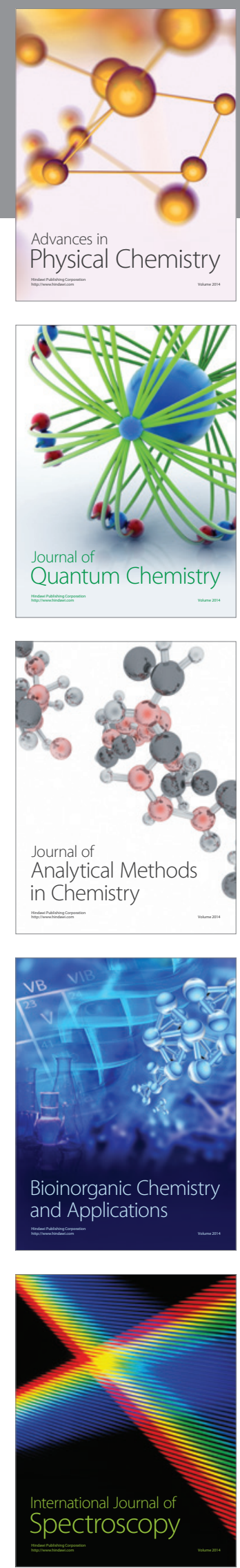